\title{
KNOWLEDGE AND PRACTICE OF CONDOM USE IN AN URBAN ADULT COMMUNITY SAMPLE OF THE NORTHERN PROVINCE, SOUTH AFRICA
}

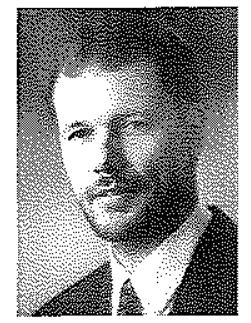

\author{
Prof. Karl Peltzer \\ Dept. of Psychology \\ University of the North
}

\begin{abstract}
There is a paucity of data concerning condom use, especially regarding knowledge about the correct use of condoms in South Africa. Therefore, the aim of the study is to investigate knowledge and sexual practices with reference to correct use of condoms among an urban adult community in the Northern Province. A cross-sectional face-to-face interview by questionnaire was conducted. Sampling was done by systematic sampling. The sample consisted of 98 participants, 40 female and 58 male, the mean age was 27.2 years $(S D=5.4)$, with a range from 18 to 45 years. Results indicated about $90 \%$ levels of correct answers for the items of 'expiry date of condons', 'condom be put on before contact with vagina', and 're-using condoms'. More than $15 \%$ were not aware that condoms offer protection against Sexually Transmitted Diseases or AIDS. The most common mistakes with respect to condom use were ignorance about the correct moment to put on a condom, inability to put on a condom properly, when to take off a condom, and the use of oil-based lubricants, in this order. A significant relationship was found between age, sex, and frequency of sexual encounters in the last three months and condom knowledge. Findings are discussed in view of condom promotion programmes.
\end{abstract}

\section{OPSOMMING}

Daar is 'n skaarste aan data oor die gebruik van kondome, meer spesifiek is daar'n gebrek aan kennis oor die korrekte gebruik van kondome in Suid Afrika. In die lig van bogenoemde is die doel van die navorsing om kennis en seksuele praktyke meer"spesifiek ten opsigte van die korrekte gebruik van kondome deur stedelike volwassenes in die Noordelike Provinsie na te vors. Daar is gebruik gemaak van die dwarssnee metode. ' $n$ Vraelys is gebruik in een-tot-een onderhoude. Steekproeftrekhing is sistematies gedoen. Die steekproef het bestaan uit 98 proefpersone waarvan 40 vroulik en 58 manlik was. Die gemiddelde ouderdom was 27.2 jaar (standaardafwyking $=5.4$ ) met ' $n$ verspreiding van 18 tot 45 jaar.Die resultate het $90 \%$ korrekte antwoorde getoon vir die items soos die volgende: vervaldatum van kondome, kondoom moet aangesit word voor kontak met die vagina, en hergebruik van kondoom. Meer as $15 \%$ van die proefpersone was nie bewus dat kondome beskerming gee teen seksueel oordraagbare siektes of Vigs nie. Die grootse gebrek aan kennis gaan oor die volgende: regte oomblik om die kondoom aan te sit, onvermoë om die kondoom korrek aan te sit, wanneer om die kondoom af te haal, en die gebruik van kondome met 'n oliebasis, spesifiek in die bogenoemde volgorde.'n Betekenisvolle korrelasie is bevind ten opsigte van ouderdom, geslag, frekwensie van seksuele omgang in die laaste drie maande en kennis van kondome. Die bevindinge word bespreek in die lig van programme om kondome te bevorder.

\section{INTRODUCTION}

One of the major ways of preventing the spread of HIV/AIDS is the use of condoms. Condom use has been shown to be more effective in preventing HIV infection than reduction in the number of sexual partners (Reiss \& Leik, 1989:411). Correct use of them reduces the risk of HIV transmission by almost 100 percent. Condom promotion has received considerable attention in the fight against the AIDS pandemic (WHO, 1995:3ff.). This is particularly important in sub-Saharan Africa where HIV transmission is mainly through sexual contact.Yet condom use is among the most difficult issues to address in designing programmes to reduce the sexual transmission of HIV in Africa.

Many authors, Health departments and organisations, and governments have recommended and developed strategies for the promotion of the use of condoms as a preventive measure against HIV/AIDS epidemic (e.g. Bengel, Belz-Merk \& Farin, 1996:513; Campbell, 1997:187; Edem \& Harvey, 1994\95:3; Green, Zokwe, and Dupree, 1995:503). Even though heterosexual condom use is often promoted solely with reference to HIV prevention, condoms are also effective in preventing the spread of sexually transmitted diseases (STD's) such as chlamydia and gonorrhoea (Sheeran \& Abraham, 1994:200; Sheeran, Abraham \& Orbell, 1999:91).

In South Africa, aversion to condom use is the dominant theme, although explanations for this vary; cultural beliefs are also a barrier to condom use in South Africa, where many people consider it essential that the sperms of the men actually enters the woman (Gould, 1993:132f.).

All in a sample of 100 urban black mothers questioned 
in Durban stated that they had never experienced sexual intercourse where their partner had used a condom (Abdool-Karim, Abdool-Karim, \& Nkomokazi, 1991:342). The highest incidence of condom use was in a sample of gold miners, where $32.6 \%$ had used them at least once (Ijesselmuiden et al. 1990:520). Browne and Minichiello (1994:232) highlighted the importance of promoting sex with a condom as good and pleasurable.

Research also shows that the spread of HIV/AIDS is on the increase. It is expected that the prevalence of AIDS will reach about $27 \%$ of the sexually active population in South Africa by the year 2010 (Webb, 1997:214).

Abdool-Karim, Abdool-Karim, Preston-Whyte and Sanker (1992:107) did an explorative qualitative study to find out reasons for lack of condom use among high school students in Natal (South Africa). They complained amongst others that condom use was not sufficiently well understood and that condoms were not accessible or available when required.

In South Africa condoms are distributed free of cost through the public distribution system and the extensive primary health care network.

There is a paucity of data concerning condom use, especially regarding knowledge about the correct use of condoms by the target group in South Africa. However, such data are crucial for prevention programmes. Therefore the present study investigates knowledge and sexual practices with reference to correct use of condoms (prevalence of condom use and factors associated with the use/non-use of condoms) among an urban adult community in the Northern Province.

The objectives of the study are:

(1) To assess the knowledge about the correct use of condoms;

(2) To determine the frequency of condom use;

(3) To assess the reasons for not using a condom; and

(4) To identify the relationship between independent variables (biographic data, sexual behaviour, condom use) and dependent variables (condom knowledge).

\section{METHODS}

\section{Sample}

The target population consisted of the general heterosexual population of both genders between 18 and 45 years of age. The minimum age was set to exclude participants who were just beginning sexual activity, the maximum age to limit age-dependent influences on sexual behaviour. The total sample included 98 participants, 40 female and 58 male, the mean age was 27.2 years $(S D=5.4)$, with a range from 18 to 45 years. Most were Northern Sotho $(73.6 \%)$,
Xitsonga (13.2\%), Venda (4.4\%), Zulu (3.3\%), and others $(5.5 \%)$. Most participants $(51.3 \%)$ had some secondary education, $20.4 \%$ had completed matric, $13.5 \%$ had primary education only, $11 \%$ some tertiary and $2.2 \%$ no education at all. Almost one-third $(29 \%)$ indicated that they were students, $27 \%$ were not working, $15 \%$ were house wives, $14 \%$ were semiprofessionals, $8 \%$ professionals, and $7 \%$ were unskilled labourers. About two-thirds (64\%) were single, 29\% were married, and $7 \%$ divorced or separated. One-fifth (22.2\%) belonged to the Zion Christian Church, 13.3\% were Roman Catholic, 10\% Lutheran, 10\% Christian Baptist of South Africa, 7.8\% Anglican, 6.7\% African religion, $5.6 \%$ Apostolic, and others $24.4 \%$.

\section{Procedure}

A cross-sectional face-to-face interview by questionnaire on sexual activity patterns and knowledge regarding the use of condoms was conducted among an adult urban community (18-45 years) in Mankweng, Northern Province. Sampling was done by systematic sampling; every 5 th household was selected for the sample using a population list based on census data. Looking at the sensitive nature of the study, all participants were assured full confidentiality and anonymity. Those who agreed to participate were interviewed with a pre-tested questionnaire in English or Northern Sotho by a trained male research assistant for male participants and a trained female research assistant for female participants. Interviewers could speak the language and dialect of the community. Interviews were completed in private in the respondent Æs home or another chosen location. To increase their comfort and understanding, respondents chose either common or technical words to describe sexual acts. An answer booklet was utilised for sensitive questions specifically on sexual behaviour. Interviewers read the questions from the questionnaire while respondents checked off answers in the booklet. When the interview was completed, respondents personally sealed the answer booklet in an envelope. The few illiterate participants were interviewed using the questionnaire without the answer booklet.

\section{Measure}

A questionnaire was pre-tested on 15 men and 15 women, who did not form part of the final sample. The final questionnaire consisted of questions about: (a) biographic data ( 8 items), (b) sexual activity and condom use (5 items) (cf. Eshetu, Zakus \& Kebede, 1997:10), (c) knowledge about correct use of condoms (10 items), and (d) reasons for not using a condom (18 items) (cf.Calzavara, 1998:277). Knowledge about correct use of condoms was evaluated as per standard guidelines for use of condoms (Sharma, Dave, Sharma \& Chauhan, 1997:711, WHO, 1990:10ff.). There were ten closed questions, each with one possible correct 
answer (e.g. when to put on a condom, how to use it correctly, how and when to take it off, the use of lubricants, etc.) and for each correct answer one point was awarded. The total points comprised the knowledge score range from 0 to 10 . Regarding reasons for not using condoms, respondents were given a list of 18 reasons and asked to indicate which applied to them.

For the 15 item scale on sexual activity, condom use and knowledge about correct use of condoms the Cronbach alpha as well as split-half reliability coefficient were .71 for this sample, and for the 18 item scale on reasons for not using a condom the Cronbach alpha as well as split-half reliability coefficients were .63 and .69 for this sample.

\section{RESULTS}

Table 1 indicates the knowledge about correct condom use among the participants.

About $90 \%$ levels of correct answers were found for the items of "expiry date of condoms", "condom be put on before contact with vagina", and "re-using condoms". More than 15\% were not aware that condoms offer protection against Sexually Transmitted Diseases (STD's) or AIDS. The most common mistakes with respect to condom use were ignorance about the correct moment to put on a condom, inability to put on a condom properly, when to take off a condom, and the use of oil-based lubricants, in this order. Generally, men had more correct knowledge on condom use than women did. There was, however, only one significant gender difference on item 8 'Is it essential for a person using a condom to withdraw his penis immediately after ejaculation?' $(p<.01)$.

Table 1: Knowledge about correct condom use by gender in percent

\begin{tabular}{|c|c|c|}
\hline Items & $\frac{\frac{\Phi}{\sigma}}{\Sigma}$ & $\frac{\frac{\mathscr{U}}{\widetilde{D}}}{\frac{E}{\mathbb{Q}}}$ \\
\hline 1. Do condoms have an expiry date? & 95 & 92 \\
\hline 2. Should a condom be put on before any contact with the vagina? & 93 & 85 \\
\hline 3. Can a condom be re-used? & 92 & 80 \\
\hline 4. Do condoms offer protection against STD's? & 88 & 78 \\
\hline 5. Do condoms offer protection against AIDS? & 82 & 82 \\
\hline 6. Should a condom be checked for leaks and holes? & 83 & 80 \\
\hline $\begin{array}{l}\text { 7. Can an oil-based lubricant (e.g. oil, Vaseline, cold cream) be used } \\
\text { with a condom? }\end{array}$ & 76 & 83 \\
\hline $\begin{array}{l}\text { 8. Is it essential for a person using a condom to withdraw his penis } \\
\text { immediately after ejaculation? }\end{array}$ & 80 & 61 \\
\hline 9. Should a condom be unrolled before being put on the penis? & 72 & 67 \\
\hline 10. Is it all right to put on a condom just before ejaculation? & 40 & 43 \\
\hline
\end{tabular}


Table 3 indicates factors associated with knowledge about condom use by the participants.

Table 3: Factors associated with knowledge about condom use

\begin{tabular}{|l|l|}
\hline Independent variables & Total condom knowledge score \\
\hline Age & $-.221^{*}$ \\
\hline Sex & $.247^{\star}$ \\
\hline Formal education & .029 \\
\hline Last sexual encounter & -.30 \\
\hline Number of sexual encounters last 3 months & $.259^{* *}$ \\
\hline Use of condom in last 3 months & .121 \\
\hline \multirow{2*}{*}{$p<.01 ;{ }^{*} p<.05$ Pearson correlation significance (2-tailed) } \\
\hline
\end{tabular}

There is a significant relationship between age, sex, and frequency of sexual encounters in the last three months and condom knowledge. Male sex, decreasing or younger age and especially increasing recent sexual encounters seem to be associated with correct condom knowledge. Formal education and condom use seems not to be related to correct knowledge about condoms.

Table 4 Reasons for not using condoms in the previous 12 months by gender and in persent

\begin{tabular}{|l|l|l|}
\hline Item & & ¿ \\
\hline 1. I was with my steady sex partner & $\sum$ & 3 \\
\hline 2. I do not have the AlDS virus & 69 & 73 \\
\hline 3. I thought I was safe & 69 & 70 \\
\hline 4. The sex was so exciting & 69 & 68 \\
\hline 5. I didn't think of using a condom & 61 & 63 \\
\hline 6. My partner said he or she did not have the AlDS virus & 55 & 64 \\
\hline 7.I did not want to use one & 50 & 68 \\
\hline 8. My partner did not want to use one & 50 & 59 \\
\hline 9. Could not talk about it & 42 & 55 \\
\hline 10. My partner got angry for suggesting using one & 42 & 38 \\
\hline 11. I did not have a condom at that time & 32 & 48 \\
\hline 12. I could not afford to buy any condoms & 33 & 38 \\
\hline 13. I was too embarrassed to get condoms & 27 & 40 \\
\hline 14. I find condoms painful & 32 & 33 \\
\hline 15. I can't obtain condoms here & & 38 \\
\hline
\end{tabular}


Table 2 indicates sexual activity and condoms use by the participants.

Almost half of the respondents were aware of condoms prior to their first sexual encounter while less than $20 \%$ used a condom on first sex. More than $70 \%$ of both men and women had a sexual encounter within the last month and about $90 \%$ within the last three months. Regarding the frequency of sexual encounter $45.8 \%$ of men and $35 \%$ of women said four times or more, and $8.4 \%$ of the men and $17.5 \%$ of the women reported none. More than one third $(35.9 \%)$ of the sample reported never using condoms, $27.5 \%$ always, $16.7 \%$ regularly and $20 \%$ irregularly in the last three months.

Table 2: Sexual activity and condom use in percent

\begin{tabular}{|c|c|c|c|}
\hline \multicolumn{2}{|l|}{ Item } & Male & Female \\
\hline \multicolumn{2}{|c|}{ Knowledge of condom prior to the first sexual encounter } & 46.7 & 42.5 \\
\hline \multicolumn{2}{|l|}{ Use of condom on the first sexual encounter } & 18.3 & 19.4 \\
\hline Last sexual encounter & $\begin{array}{l}-1-5 \text { days } \\
-1-2 \text { weeks } \\
-3-4 \text { weeks } \\
-1-3 \text { months } \\
\text {-more than } 3 \text { months }\end{array}$ & $\begin{array}{l}31.7 \\
21.7 \\
20.0 \\
21.7 \\
05.0\end{array}$ & $\begin{array}{l}43.6 \\
23.1 \\
10.3 \\
20.5 \\
02.6\end{array}$ \\
\hline $\begin{array}{l}\text { Frequency of sexual encounter during the } \\
\text { last } 3 \text { months }\end{array}$ & $\begin{array}{l}\text {-None } \\
\text {-Once } \\
\text {-Twice } \\
\text {-Three times } \\
\text {-Four or more }\end{array}$ & $\begin{array}{l}10.3 \\
10.3 \\
20.7 \\
10.3 \\
48.3\end{array}$ & $\begin{array}{l}17.5 \\
22.5 \\
17.5 \\
07.5 \\
35.0\end{array}$ \\
\hline $\begin{array}{l}\text { Condom use when having sexual } \\
\text { intercourse in the past } 3 \text { months }\end{array}$ & $\begin{array}{l}\text {-every time } \\
\text {-regular }^{1} \\
\text {-irregular }{ }^{2} \\
\text {-never }\end{array}$ & $\begin{array}{l}25.0 \\
18.3 \\
19.9 \\
36.7\end{array}$ & $\begin{array}{l}30.0 \\
15.0 \\
20.0 \\
35.0\end{array}$ \\
\hline
\end{tabular}

${ }^{1}$ Regular: almost always, more often than not

${ }^{2}$ Irregular: about half the time, somewhat less than half the time, rarely 


\begin{tabular}{|l|l|l|}
\hline 16. Wanted pregnancy & 12 & 37 \\
\hline 17. I was forced to have sex against my will & 12 & 30 \\
\hline 18. I was using alcohol or drugs & 10 & 23 \\
\hline
\end{tabular}

The most common reasons for not using a condom were 'I was with my steady sex partner'(71\%), 'I did not have the AIDS virus' $(70 \%)$, and 'I thought I was safe' (69\%). On most items women scored higher than men on reasons for not using condoms. Noteworthy is that $30 \%$ of the women said that they did not use a condom because they were forced to have sex against their will.

\section{DISCUSSION}

In this study more than one third (35.9\%) of the sample reported never using condoms, $27.5 \%$ always, $16.7 \%$ regularly and $20 \%$ irregularly in the last three months. Although time trend analyses show that condom use has increased among heterosexuals, the absolute level of use remains low, as shown in this sample. A nationally representative survey of people in the United Kingdom and France found that $40-60 \%$ of the sexually active sample had not used a condom during the previous 12 months. Similar percentages of condom non users have been reported in the National AIDS Behavioural Surveys in the United States (Sheeran et al. 1999:91). Studies among African populations found lower or similar rates of condom use, e.g. among Ugandan university students condoms had only been used by $35 \%$ men and $24 \%$ of women (Lule \& Gruber, 1991:16) and $47.9 \%$ of Ethiopian students had used a condom at least once in the last six months (Kidan \& Azeze, 1995:8). Thus there is considerable scope for improving rates of heterosexual condom use.

The overall knowledge about correct condom use was high in this sample. In a study among sexually active men in India a much higher level of ignorance about condom use was found. However, the most common mistakes were similar as in this sample although in a somewhat different order, e.g. the use of oil-based lubricants $(6.6 \%$ correct answers), or the correct moment to put on a condom ( $10.1 \%$ correct answers).

Male sex, decreasing or younger age and especially increasing recent sexual encounters seem to be associated with correct condom knowledge. Formal education seems not to be related to correct knowledge condom use. Mnyika, Klepp, Kvale, Schreiner and Seha (1995:180) also found in a cross-sectional sample (ages 15-54) in Tanzania that educational status was not a significant determinant of condom awareness and use, while age and gender was.

The reasons for not using a condom in this study were similar to those found among South African university students: perceived invulnerability $(70 \%$ believed that they did not have the AIDS virus), stage of relationship, gender role expectations, male-female power relations, negative attitudes towards condoms, and unavailability of condoms (Madu \& Peltzer, 1999:85f.; Wood \& Foster, 1995:13).

\section{CONCLUSION}

Given that rates of condom use were low, condom promotion should be intensified. Considering the results of this study, condom promotion efforts should specifically address women, the older age group and those who have more frequent sexual encounters.

Moreover, condom promotion needs to consider, as found in this study, the high rate of barriers between (steady) partners to use condoms such as 'my partner did not want to use one' (49\%) and 'could not talk about it' $(40 \%)$ and the high reported rate of unavailability of condoms, such as 'I could not afford to buy any condoms' (34\%) or 'I can't obtain condoms here' (29\%). Nicholas (1999: 893) suggests from a survey of South African university students that condomvending machines and a wider range of distribution points for free condoms could ease the unpleasantness of purchases.

\section{Acknowledgements}

I thank the University of the North for the financial support and Rita Olwagen for statistical assistance.

\section{REFERENCES}

Abdool-Karim, Q; Abdool-Karim, SS \& Nkomokazi, J 1991: Sexual behaviour and knowledge of AIDS among urban black mothers. South African Medical Journal, 80, 1991:340-343.

Abdool-Karim, SS; Abdool-Karim, Q; Preston-Whyte, E \& Sankar, N 1992: Reasons for lack of condom use among high school students. South African Medical Journal, 82(2), 1992:107-110.

Browne, J \& Minichiello, V 1994: The condom: why more people don't put it on. Sociology of Health and Illness, 16, 1994:228-250.

Bengel, $J$; Belz-Merk, $M$ \& Farim, E 1996: The role of risk perception and efficacy cognitions in the prediction of HIV-related preventive behaviour and condom use. Psychology and Health, 11, 1996:505-525. Campbell, T 1997: How can psychological theory help to promote 
condom use in sub-Saharan African developing countries. Journal of the Royal Society of Health, 117, 1997:186-191.

Calzavara, LM; Burchell, AN; Meyers, T; Bullock, SL; Escobar, M \& Cockerill R 1998: Condom use among aboriginal people in Ontario, Canada. International Journal of STD \& AIDS, 9, 1998:272-279.

Edem, CU \& Harvey, SM 1994195: Use of the Health Belief Model to predict condom use among university students in Nigeria. International Quarterly of Community Health Education, 15, 1994/1995:3-14.

Eshetu, F; Zakus, D \& Kebede, D 1997: The attitudes of students, parents and teachers towards the promotion and provision of condoms for adolescents in Addis Ababa. Ethiopian Journal of Health Development, 11 , 1997:7-16.

Gould, P 1993: The slow plague. London: Blackwell.

Green, EC; Zokwe, B \& Dupree, JD 1995: The experience of an AIDS prevention program focused on South African traditional healers. Social Science and Medicine, 40(4), 1995:503-515.

Ijesselmuiden, LB; Padayachee, GN; Mashaba, W; Martiny, O \& Van Staden HP 1990: Knowledge, beliefs and practices among black goldminers relating to the transmission of HIV and other sexually transmitted disease. South African Medical Journal, $78,1990: 520-523$.

Kidan, KG \& Azeze, B 1995: Survey of condom use among college students. Ethiopian Journal of Health Development, 9, 1995:7-11.

Lule, GS \& Gruber, LD 1991: Sexual behaviour and use of condom among Ugandan students. AIDS CARE, 3, 1991:11-19.

Madu, SN \& Peltzer, K 1999: Complaints of university students about male use of condoms as a preventive measure against HIV/AIDS in South Africa. Journal of Psychology in Africa, 9, 1999:78-90.

Mnyika, KS; Klepp, KI; Kvale, G; Schreiner, A \& Seha, AM 1995: Condom awareness and use in the Arusha and Kilimanjaro regions, Tanzania: a population-based study. AIDS Education and Prevention, 7, 1995:403414.

Nicholas, LJ 1998: Black South African students $\mathbb{E}$ beliefs and attitudes about condoms.Psychological Reports, 83, 1998:891-894.

Reiss, IL \& Leik, RK 1989: Evaluating strategies to avoid AIDS: numbers of sexual partners versus use of condoms. Journal of Sex Research, 26, 1989:411-433.
Sharma, V; Dave, S; Sharma, A \& Chauhan, P 1997: Condoms: mis-use $=$ non-use. The condom equation in Gujarat, India. AIDS CARE, 9, 1997:707-713.

Sheeran, P \& Abraham, C 1994: Measurement of condom use in 72 studies of HIV-preventive behaviour: a critical review. Patient Education and Counselling, 24, 1994:199-216.

Sheeran, P; Abtaham, C \& Orbell, S 1999: Psychosocial correlates of heterosexual condom use:

a meta-analysis. Psychological Bulletin, 125. 1999:90-132.

Webb, D 1997: HIV and AIDS in Africa. Cape Town: David Philip.

Wood, C \& Foster, D 1995: "Being the type of lover...": gender differentiated reasons for non-use of condoms by sexually active heterosexual students. Psychology in Society, 20, 1995:13-35.

World Health Organization 1990: Global programme on AIDS: orientation manual: condom and virucide services. Geneva: author.

World Health Organisation 1995: Condom promotion for AIDS prevention. Geneva: author. 